\title{
SIMKARTU (SISTEM MONITORING KUALITAS AIR TAMBAK UDANG) BERBASIS ARDUINO DAN SMS GATEWAY
}

\author{
Ahmad Septian Pratama ${ }^{1}$, Ahmad Heri Efendi ${ }^{2}$, Dimas Burhanudin ${ }^{3}$, Muhammad Rofiq $^{4}$ \\ 1, ,2,3,4 STMIK Asia Malang
}

\section{Article Info:}

Dikirim: 28 Mei 2019

Direvisi: 10 Juni 2019

Diterima: 20 Juni 2019

Tersedia Online: 29 Juni 2019

Penulis Korespondensi:

Ahmad Septian Pratama

Stmik Asia Malang,

Indonesia

Email: ahmadseptian107@gmail.com

\begin{abstract}
Abstrak: Dalam budidaya tambak udang, untuk pengecekan kandungan pH air para petani tambak kebanyakan memakai cara konvensional, yaitu dengan mengukur menggunakan pH meter digital ataupun kertas lakmus secara periodik. Sistem pembacaan pH manual membuat penanganan lambat padahal udang adalah hewan yang sensitif dengan perubahan kualitas air. Proses pengecekan yang dilakukan secara periodik kebanyakan membuang-buang waktu, dan tingkat kesalahan manusia yang tinggi. Didalam sistem cara kerja sistem monitoring $p H$ air tambak udang adalah kadar $\mathrm{pH}$ dibaca sensor lalu di olah di mikrokontroler arduino mega, setelah pemerosesan selesai akan di tampilkan pada layar LCD secara realtime. Ketika kadar pH mengalami perubahan status dari normal ke tinggi, normal ke rendah, rendah ke normal, dan tinggi ke normal maka alat akan mengirimkan peringatan melalui SMS Gateway ke handphone petani tambak udang. Dari hasil pengujian sistem secara keseluruhan menunjukan bahwa sistem telah mampu mengirim pesan sms pada setiap perubahan status. Pengujian pada lokasi tambak memiliki nilai rata-rata pH sebesar 7,68.
\end{abstract}

Kata kunci: arduino; monitoring; ph air; sms gateway; tambak udang.

\begin{abstract}
In the cultivation of shrimp ponds, to check the $\mathrm{pH}$ content of the water, most pond farmers use conventional methods, namely by measuring using a digital pH meter or litmus paper periodically. Manual $\mathrm{pH}$ reading system makes handling slow even though shrimp are animals that are sensitive to changes in water quality. The periodic checking process is mostly a waste of time, and a high level of human error. In terms of the way the system works in shrimp pond water $\mathrm{pH}$ monitoring is the $\mathrm{pH}$ level sensor that is read and processed in the microcontroller arduino mega, after processing is complete will be displayed on the LCD screen in realtime. When the $\mathrm{pH}$ level changes status from normal to high normal to low, low to normal, and normal to high then the tool will send an alert to a mobile phone via SMS Gateway shrimp farmers. From the results of the overall system testing shows that the system has been able to send SMS messages on any status changes. Tests on farm locations have an average $\mathrm{pH}$ value of 7.68 .
\end{abstract}

Keywords: shrimp; arduino; sms gateway; monitoring; water ph. 


\section{PENDAHULUAN}

Tambak merupakan salah satu jenis habitat yang dipergunakan untuk kegiatan budidaya air payau yang berada di pesisir, dimana kegiatan budidaya yang dilakukan secara terus menerus dapat menyebabkan terjadinya degradasi terhadap lingkungan, yang ditandai dengan menurunnya kualitas air [1]. Budidaya tambak membantu para nelayan dalam memperoleh hasil dengan kualitas dan kuantitas yang diinginkan tanpa merusak lingkungan dan keanekaragaman hayati [8]

Dalam budidaya udang air payau, untuk mengontrol kadar $\mathrm{pH}$ para petani tambak udang masih menggunakan cara konvensional, yaitu dengan cara mengukur menggunakan $\mathrm{pH}$ meter digital maupun menggunakan kertas lakmus, lalu para petani menambahkan sejumlah air tawar/laut sebanyak yang diperlukan dan mengukur lagi dengan cara di atas apakah air sudah benar-benar netral atau belum [1]. Sedangkan menurut Kusrini dkk, [3] cara konvensional lain yaitu dengan mengambil sampel air kemudian dibawa ke laboratorium untuk dianalisa. Proses monitoring yang dilakukan secara periodik cenderung tidak praktis, membutuhkan upah yang mahal, dan tingkat human error yang besar. mengontrol kualitas ph air paling ideal dilakukan setiap hari dikarena banyak sekali faktor - faktor yang memicu terjadinya perubahan kualitas ph air, salah satunya seperti hujan, terik panasnya sinar matahari yang seharian, masuknya material - material asing asing ke tambak dan lain - lain [1]. Salah satu kendala bagi para petani tambak udang adalah dalam pengecekan kualitas ph air secara realtime

Berdasarkan permasalahan di atas di butuhkan sebuah alat yang dapat mempermudah proses monitoring tambak udang. Sensor $\mathrm{pH}$ pada prinsipnya adalah alat yang dapat mengukur Kadar $\mathrm{pH}$ dalam air yang dapat di kontrol lewat mikrokontroler. Arduino merupakan salah satu sistem mikrokontroller yang berbasis open source. Istilah arduino dapat dibagi menjadi dua sistem yaitu hardware dan software. Dengan sistem open source baik pada hardware maupun software-nya dapat memberikan inspirasi yang cukup banyak pada perancangan sistem elektronika [2]. untuk memper mudah petani tambak udang untuk memonitoring keadaan air di butuhkan media informasi yang mudah untuk di fahami dan di operasikan dan salah satu metode adalah dengan cara mengirim sms keadaan air tambak ke hp petani memanfaatkan sms gateway.

Dengan memanfaatkan sensor $\mathrm{pH}$ air yang dapat di kontrol dengan arduino dan mengunakan komunikasi sms gateway maka Akan dibangun sebuah alat yang dapat memantau (monitoring) nilai parameter $\mathrm{pH}$ air pada tambak udang mengunakan arduino dengan memanfaatkan media komunikasi sms gateway.

\section{METODOLOGI PENELITIAN}

\subsection{Analisis Komponen Perangkat Keras Sistem}

Analisis komponen perangkat keras merupakan komponen perangkat keras apa saja yang akan dibutuhkan untuk membangun sistem informasi presensi. Komponen sistem informasi yang akan digunakan diantaranya sebagai berikut:

a. $\quad$ PH meter v1.1, merupakan alat yang di gunakan untuk membaca nilai kadar $\mathrm{pH}$ dalam air.

b. Arduino Mega, merupakan komputer papan tunggal(Single Board Circuit ) yang akan digunakan sebagai CPU pada sistem monitoring yang akan mengolah dan mengirim data hasil monitoring.

c. LCD $2 \times 16$, digunakan untuk menampilkan hasil monitoring kadar $\mathrm{pH}$ air secara langsung dan terus menerus.

d. Modul Sim800L, digunakan sebagai alat pengirim hasil monitoring ke handphone petani tambak udang melalui sms jika batas kadar ph melampaui ketentuan yang sudah di atur.

e. Modul LM2596, digunakan sebagai penurun tegangan yang bersifat bisa di atur di gunakan sebagai sumber tegangan utuk modul sim $800 \mathrm{~L}$ yang bekerja di tegangan 3,7 volt.

\subsection{Analisis Komponen Perangkat Lunak Sistem}

Analisis komponen perangkat lunak merupakan komponen perangkat lunak apa saja yang akan dibutuhkan untuk membangun sistem monitoring tambak udang. Komponen sistem monitoring yang akan digunakan mengunakan bahasa pemerograman C yaitu Arduino IDE. merupakan sebuah software untuk menjalankan arduino yang digunakan untuk mengkordinasikan modul-modul yang di pakai dan megolah data dari sensor menjadi sebuah informasi yang akan di tampilkan di layar lcd dan sms gateway.

\subsection{Perancangan Perangkat Keras Sistem}

Dalam perancangan alat ini, terlebih dahulu dibuatkan blok diagram secara keseluruhan yang kemudian dirancang penjabaran tiap bloknya. Blok diagram keseluruhan ditunjukan dalam Gambar 1. 


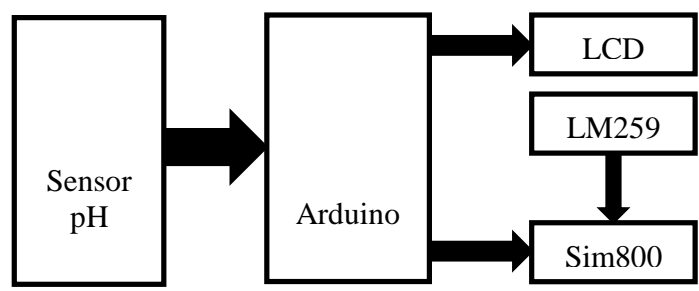

Gambar 1. Blok Diagram Keseluruhan

Penjelasan Blog Diagram Keseluruhan sistem:

a. Sensor $\mathrm{pH}$ terhubung ke arduino sebagai input sensor baca $\mathrm{pH}$

b. Arduino ke lcd 2X16 untuk menampilkan hasil baca sensor

c. Arduino ke Sim 8001 mengirim pesan sms ke pengguna

d. Lm2596 ke Sim 8001 sumber tegangan 3,7 volt di sim 8001

\subsection{Perancangan Rangkaian}

Pada perancangan ini akan di buat gambaran perancangan keseluruhan hardware yang terdiri dari arduino mega yang berfungsi sebagai mikrokontroler dan akan megolah data yang di terima dari sensor ph meneruskan hasil olah data ke led 2 X16 dan sim 8001, sensor pH air V1.1 berfungsi mengambil data ph air secara langsung dan terus meneru, lcd 2X16 menampilkan hasil baca sensor yang telah di proses di arduino mega secara terus menerus dan memberi peringata jika ada perubahan parameter yang tejadi pada ph air tambak, sim 8001 mengirim data sms pengguna jika ada perubahan parameter ph air baik itu melebihi ataupun di bawa kadar ph air yang tela di tentukan dan $\operatorname{lm} 2596$ sebagai sumber teganggan 3,7 volt pada sim 8001 yang pada prakteknya teggangan outputnya dapat di seting sesuai kebutuhan. Adapun perancangan rangkaian keseluruhan sistem ditunjukkan dalam Gambar 2.

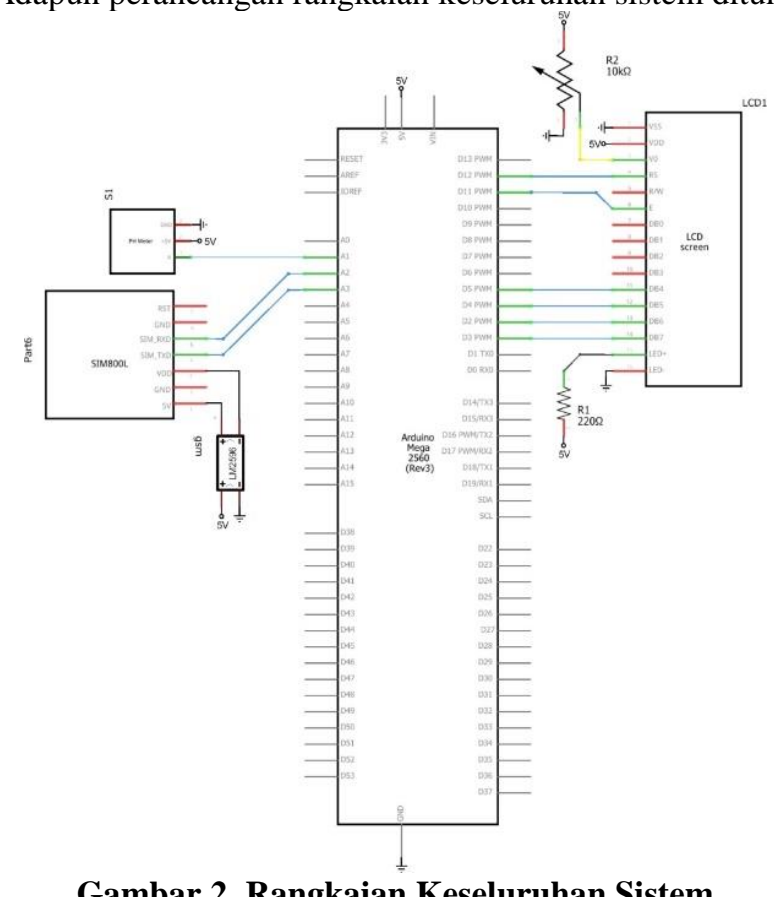

\subsection{Perancangan Flowchart Keseluruhan}

Meliputi cara kerja atau mengoperasikan keseluruhan kompenen yang di gunakan pada sistem monitoring tambak udang meliputi sensor $\mathrm{pH}$ air, lcd 2X16, sim 8001 dan modul lm2596 yang terhubung ke Arduino. Adapun perancangan Flowchart cara mengoperasikan cara kerja keseluruhan rancangan yang terhubung ke arduino mega yang di tunjukan dalam Gambar 3. 


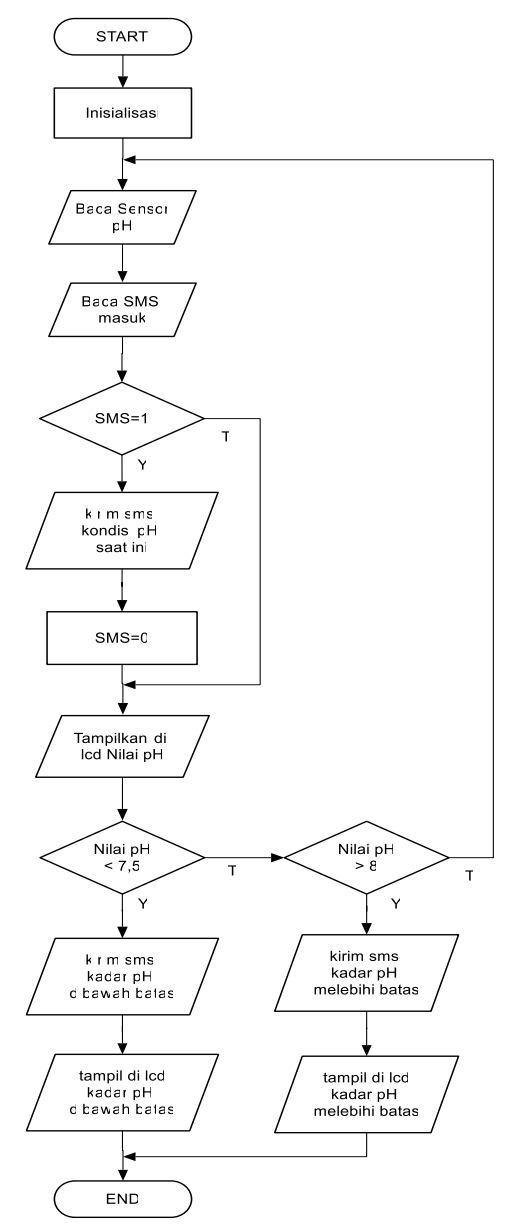

Gambar 3. Flowchart Cara Kerja Rancanggan

Flowchart cara mengoperasikan cara kerja keseluruhan rancangan yang terhubung ke arduino mega yang di tunjukan dalam Gambar 3.9 yaitu untuk proses monitoring kadar $\mathrm{pH}$ pada tambak udang dengan cara kerja sensor membaca nilai $\mathrm{pH}$ air terus hasil baca sensor di tampilkan pada layar lcd jika kadar $\mathrm{pH}$ di bawah 7,5 maka akan megirim sms ke pengguna yang berisi pesan kadar $\mathrm{pH}$ di bawah batas yang telah di tetapkan dan menampilkan di layar lcd tulisan kadar ph di bawah batas normal begitu pula jika kadar $\mathrm{pH}$ di atas 8 maka akan megirim sms ke pengguna yang berisi pesan kadar $\mathrm{pH}$ di atas batas yang telah di tetapkan dan menampilkan di layar lcd tulisan kadar ph di atas batas normal.

\section{HASIL DAN PEMBAHASAN}

\subsection{Perangkat Keras}

Implementasi perangkat keras yaitu rangkaian sensor pH, LCD, SIM800L dan Arduino mega, yang akan di implementasikan dari sekema perancangan perangkat keras yang telah di buat sebelumnya. Adapun rangkaian Keseluruhan komponen yang terdiri dari arduino mega, sim 8001, sensor PH dan LCD ditunjukkan dalam Gambar 4.

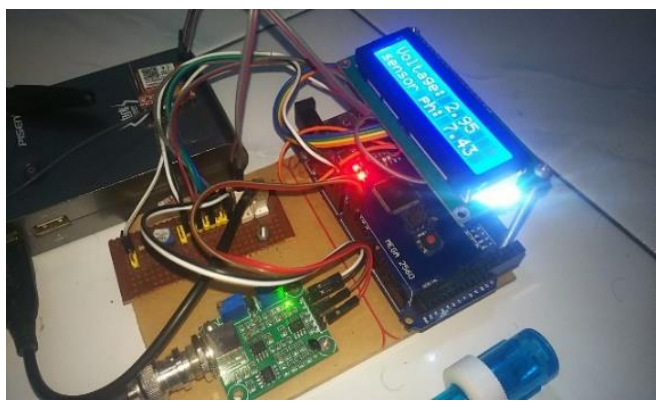

Gambar 4. Implementasi Rangkaian Keseluruhan 


\subsection{Pengujian Keseluruhan}

Pengujian rangkaian keseluruhan di lakukan dengan mengabungkan modul sensor $\mathrm{pH}$, LCD 16x2, dan SIM 8001 ke Arduino serta mengunakan handphone untuk kumunikasi dengan arduino mega serta mengunakan cairan asam dan basa untuk kalibrasi dan pengetasan sensor $\mathrm{pH}$ air serta mengunakan kertas lakmus sebagai alat pembading sensor $\mathrm{pH}$.

Bertujuan untuk mengetahui eror atau masalah yang di hadapi dalam pembuatan alat dan pengimplementasian perancangan alat yang telah di buat ke dalam bentuk sesungguhnya yang akan di terapkan langsung ke lapangan. Serta pengujian ini dapat mengetahui ke akuratan dan kesetabilan dari alat monitoring kualitas air di tambak udang dalam melakukan pembacaan kadar $\mathrm{pH}$ air, menampilkan di lcd dan mengirim sms jika kadar $\mathrm{pH}$ air melebihi atau kurang dari batas normal yang telah di tetapkan.

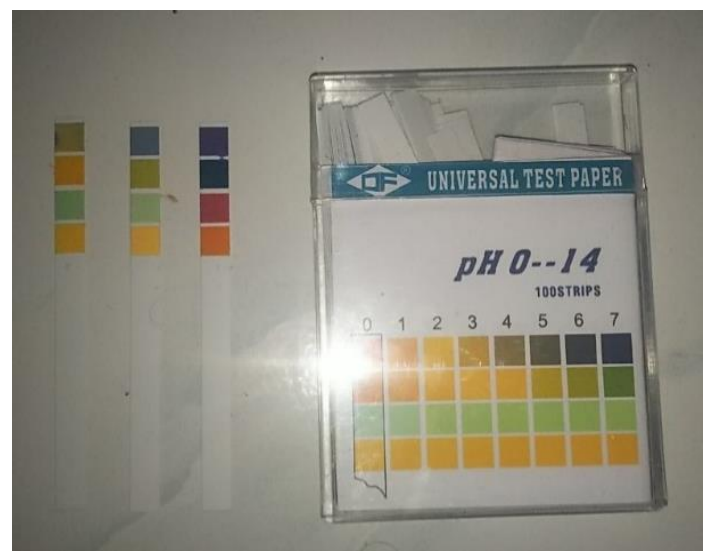

Gambar 5. Hasil Membaca Kondisi Ph dengan Kertar Lakmus sebagai Pembanding

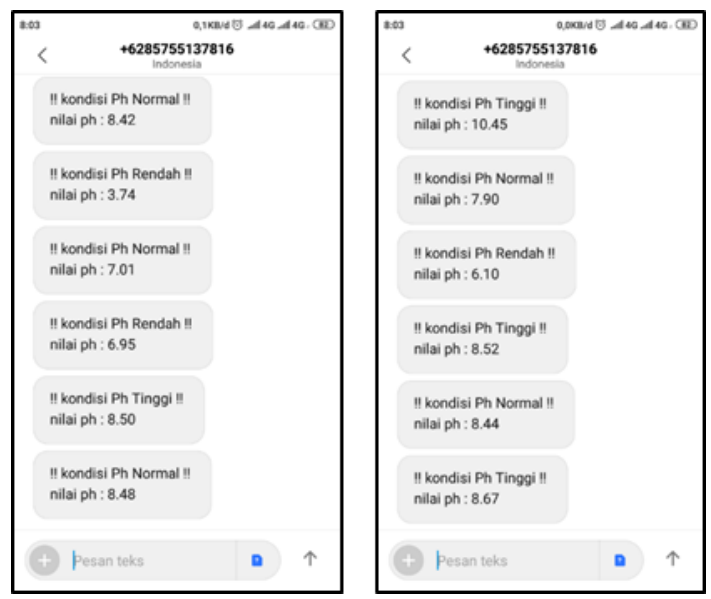

Gambar 6. Hasil SMS Peringatan jika terjadi Perubahan Nilai pH

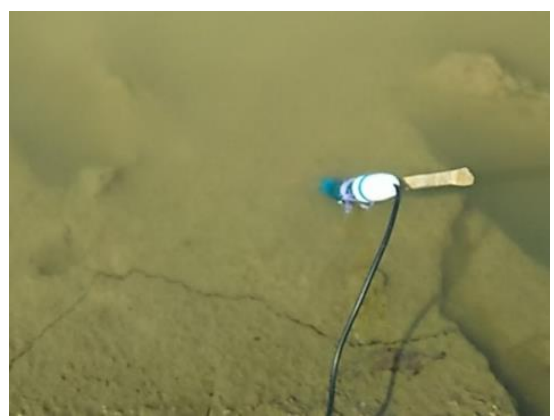

Gambar 7. Hasil Penggujian Alat di Lokasi Tambak 
Tabel 1. Implementasi sensor pH di tambak udang

\begin{tabular}{cc}
\hline Hari & Tambak \\
\hline 1 & 7,68 \\
2 & 7,68 \\
3 & 7,68 \\
4 & 7,68 \\
5 & 7,68 \\
6 & 7,68 \\
7 & 7,67 \\
\hline
\end{tabular}

Analisa dari tabel pengujian sensor pH di tambak udang selama 7 hari di lokasi tambak udang hasil tambak menampilkan nilai 7,6 dimana tambak tersebut sudah memenuhi sarat $\mathrm{pH}$ normal yaitu dengan nilai $\mathrm{pH}$ normal (7 $-8,5)$.

\section{KESIMPULAN}

Dari pembahasan yang telah dijelaskan pada bab-bab sebelumnya, dapat ditarik kesimpulan bahwa tujuan penelitian ini sudah tercapai, yaitu merancang dan membuat sistem monitoring kadar air pada tambak udang berbasis arduino mega dengan sms gateway, sehingga dapat membantu petani tambak udang dalam memonitoring kualitas air sehingga petani dapat menigkatkan kualitas air tambak udang dan hasil panen.

Dari hasil pengujian komponen - komponen dan keseluruhan rangkaian dapat disimpulkan bahwa

a. Sistem monitoring $\mathrm{pH}$ pada air tambak udang ini memiliki ketelitian pembacaan 0,01 .

b. Untuk kalibrasi alat digunakan kertas lakmus sebagai pembanding. Dan hasil pengujian menunjukkan pembacaaan alat sesuai dengan pembacaan pada kertas lakmus dengan perbedaan 2 angka dibelakang koma.

c. Sistem telah mampu mengirimkan pesan sms pada setiap perubahan status. Status $\mathrm{pH}$ air yaitu normal, asam, dan basa.

Pengujian alat pada lokasi penelitian dilakukan di 2 lokasi tambak yang dilakukan selama 7 hari dengan monitoring data setiap hari ( 7 data). Untuk tambak 1 rata-rata $\mathrm{pH}$ selama 7 hari adalah 6,84 dan tambak 2 rata-rata $\mathrm{pH}$ adalah 7,68. Selama 7 hari itu tidak ada perubahan status sehingga tidak ada pesan sms yang terkirim.

\section{DAFTAR PUSTAKA}

[1] Alimuddin., 2012. Sistem Pengendalian Kadar pH, Suhu, dan Level Air Pada Model Miniatur Tambak Udang. Politeknik Katolik Saint Paul Sorong.

[2] Arisandi Effendi Dodi., 2014. Kemudahan Pemrograman Mikrokontroller Arduino Pada Aplikasi Wahana Terbang. SETRUM.

[3] Kusrinia Priyani., 2016. Sistem Monitoring Online Kualitas Air Akuakultur untuk Tambak Udang Menggunakan Aplikasi Berbasis Android. Bandung. Jurnal elektronika dan telekomunikasi.

[4] Setianingrum Diah Ratna., 2014. Analisis Kesesuaian Lahan Tambak Menggunakan Sistem Informasi Geografis. Jurnal Geodesi Undip. 2014. 